\title{
Perineuronal Satellitosis
}

National Cancer Institute

\section{Source}

National Cancer Institute. Perineuronal Satellitosis. NCI Thesaurus. Code C98382.

A morphologic finding that refers to the accumulation of glial cells encircling neurons in a tissue specimen. 